\title{
Beyond genetics. Influence of dietary factors and gut microbiota on type 1 diabetes
}

Nielsen, Dennis Sandris; Krych, Lukasz; Buschard, Karsten; Hansen, Camilla Hartmann Friis; Hansen, Axel Jacob Kornerup

Published in:

FEBS Letters

DOI:

10.1016/j.febslet.2014.04.010

Publication date:

2014

Document version

Early version, also known as pre-print

Citation for published version (APA):

Nielsen, D. S., Krych, L., Buschard, K., Hansen, C. H. F., \& Hansen, A. J. K. (2014). Beyond genetics. Influence of dietary factors and gut microbiota on type 1 diabetes. FEBS Letters, 588(22), 4234-4243.

https://doi.org/10.1016/j.febslet.2014.04.010 


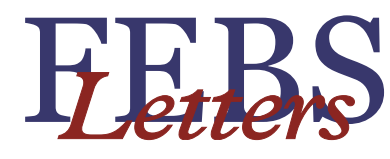

journal homepage: www.FEBSLetters.org

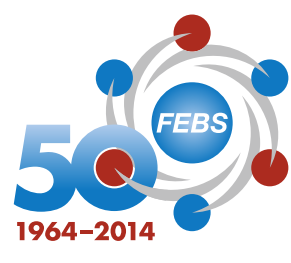

Review

\title{
Beyond genetics. Influence of dietary factors and gut microbiota on type 1 diabetes
}

\author{
Dennis S. Nielsen ${ }^{\mathrm{a}, *}$, tukasz Krych $^{\mathrm{a}}$, Karsten Buschard ${ }^{\mathrm{b}}$, Camilla H.F. Hansen ${ }^{\mathrm{c}}$, Axel K. Hansen ${ }^{\mathrm{c}}$ \\ ${ }^{a}$ Department of Food Science, Faculty of Science, University of Copenhagen, 1958 Frederiksberg C, Denmark \\ ${ }^{\mathrm{b}}$ Bartholin Institute, Rigshospitalet, 2100 Copenhagen, Denmark \\ ${ }^{\mathrm{c}}$ Department of Veterinary Disease Biology, Faculty of Health and Medical Sciences, University of Copenhagen, 1871 Frederiksberg C, Denmark
}

\section{A R T I C L E I N F O}

\section{Article history:}

Received 24 February 2014

Revised 4 April 2014

Accepted 7 April 2014

Available online 18 April 2014

Edited by Lloyd H. Kasper and Wilhelm Just

\section{Keywords:}

Type 1 diabetes

Etiology

Diet

Gut microbiota

\begin{abstract}
A B S T R A C T
Type 1 diabetes (T1D) is an autoimmune disease ultimately leading to destruction of insulin secreting $\beta$-cells in the pancreas. Genetic susceptibility plays an important role in T1D etiology, but even mono-zygotic twins only have a concordance rate of around $50 \%$, underlining that other factors than purely genetic are involved in disease development. Here we review the influence of dietary and environmental factors on T1D development in humans as well as animal models. Even though data are still inconclusive, there are strong indications that gut microbiota dysbiosis plays an important role in T1D development and evidence from animal models suggests that gut microbiota manipulation might prove valuable in future prevention of T1D in genetically susceptible individuals.
\end{abstract}

() 2014 Federation of European Biochemical Societies. Published by Elsevier B.V. All rights reserved.

\section{Introduction}

Type 1 diabetes (T1D) or insulin-dependent diabetes is an autoimmune disease ultimately leading to destruction of insulin secreting $\beta$-cells in the Langerhans islets within the pancreas [1]. With destruction of the $\beta$-cells the body losses control of blood glucose levels leading to hypoglycaemia, ketoacidosis and with time blindness, renal failure, and cardiovascular disease [1,2]. If left untreated T1D is deadly and even with well-managed insulin replacement T1D will still shorten life-expectancy with as much as $\approx 10$ years $[1,3]$. Millions are diagnosed with T1D worldwide, and in general incidence rates are increasing exerting pressure on health and welfare systems [4], though this increase seems to level of in some countries $[5,6]$.

The exact cause(s) of T1D development are not completely understood, but appears to be a combination of genetic predisposition and one or several environmental events [1]. A long list of genetic loci predisposing for T1D development have been identified, with specific HLA (Human Leukocyte Antigen) genotypes being the strongest identified genetic factor [1,7-9]. However, genetic predisposition is not the only factor leading to development of T1D. Twin studies have shown that for di-zygotic twins

\footnotetext{
* Corresponding author. Address: Department of Food Science, University of Copenhagen, Rolighedsvej 26, 1958 Frederiksberg C, Denmark.

E-mail address: dn@food.ku.dk (D.S. Nielsen).
}

the pairwise T1D concordance rate is ca. $10 \%$, and even for mono-zygotic twins the concordance rate is only around $50 \%$, while the incidence for individuals without first degree relatives affected by T1D has been estimated to be around $0.4 \%[9,10]$, though with very large regional differences [11-13]. Further, the T1D incidence in Finland is 6 times higher than on the other side of the border in Russian Karelia, even though the predisposing HLA genotypes are equally frequent between the two populations [14] and immigrant studies have shown that the offspring of immigrants tend to approach the "risk profile" of the country they moved to [15-20], underlining that more than purely genetic factors drive T1D etiology (Fig. 1).

\section{Dietary factors influencing T1D incidence and development}

\subsection{Infant feeding}

The possible protective role of breastfeeding on T1D remains an unsettled issue, as some studies have shown a protective effect while others show no effect [21-25]. However, a recent meta-analysis of 43 studies found that breast-feeding tends to offer some, although limited protection against T1D development [26]. Similarly, early exposure to cow's milk protein (i.e. through infant formula) has in some studies been found to increase the risk of developing $\beta$-cell immunity and later T1D [15,22,23,27], but the results remain somewhat contradictory, as other studies found 


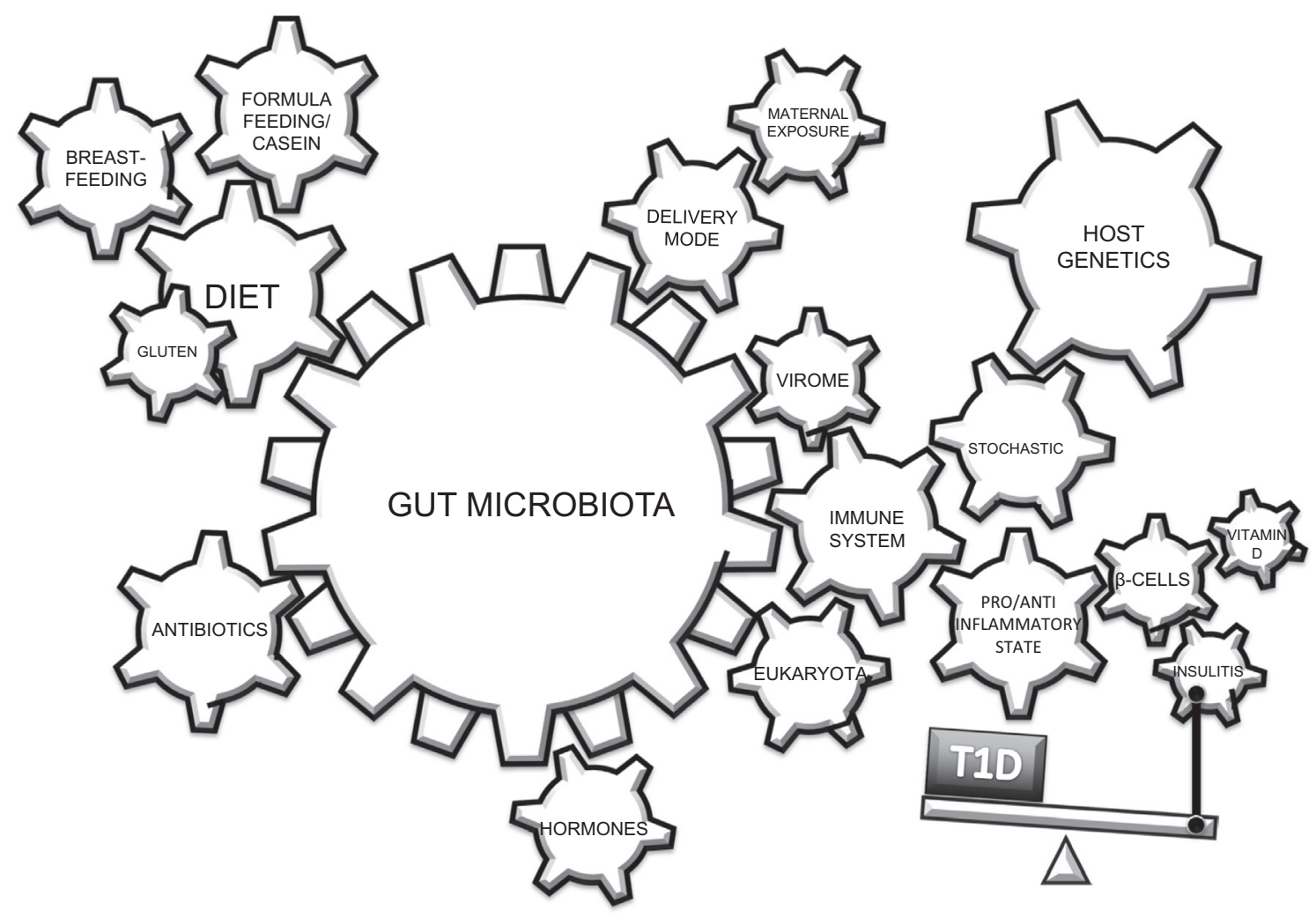

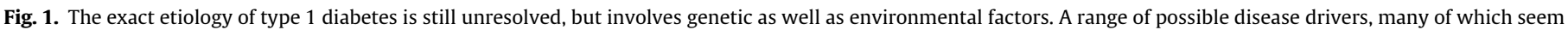
to be mediated via the gut microbiota, have been identified. See text for further details.

no effect [15,25,28,29]. However, recent studies using highly hydrolysed casein formula have showed promising results lowering T1D incidence in non-obese diabetic (NOD) mice, a mouse strain that spontaneously develop leukocytic infiltrations of pancreatic islets that subsequently develops into T1D with varying onset time and incidence depending on environmental factors $[30,31]$. Further, in humans, highly hydrolysed casein reduced the cumulative incidence of one of more T1D-associated antibodies with more than $50 \%$ in young ( $c a .5$ years) genetically predisposed children [32]. Knip et al. [32] speculate that the protective effect of the extensively hydrolysed casein formula could be due to (1) elimination of intact bovine insulin (that is present in cow's milk) by the protein hydrolysis carried out during the preparation of the formula; (2) decreased gut permeability, possibly mediated by the many short peptides present in the extensively hydrolysed formula, leading to less foreign peptides and proteins migrating into the gut associated lymphoid tissue (GALT) in the lamina propria, leading to better regulation of the gut associated immune system; (3) induced maturation of regulatory $T$ cells, through an yet unknown mechanism; and/or (4) changed gut microbiota (GM) composition, that again influence immune system development [32]. A recent Finnish study seems to confirm the protective effect of removing bovine insulin from cow's milk based infant formula, as children fed bovine insulin free formula had significantly lower cumulative incidence of $\beta$-cell autoimmunity at the age of 3 years compared to children fed traditional whey based infant formula [33].

After weaning, excessive intake of cow's milk (more than $540 \mathrm{~g} /$ day) has been linked with a significantly increased risk of developing T1D, especially in children with HLA-DQB1 genotypes conferring an increased risk of T1D development [34]. The exact cause is not known, but large intake of casein has been associated with high T1D incidence in NOD mice [35] and the per capita consump- tion of casein variants $A^{1}$ and $B$ has been linked with T1D incidence [36]. Possibly because casein variants $A^{1}$ and $B$ yield $\beta$-casomorphin-7 when enzymatically cleaved, while casein variant $A^{2}$ does not, due to a slightly different amino acid composition. $\beta$-Casomorphin-7 has in vitro been shown to inhibit intestinal lymphocyte proliferation and is speculated to have immunosuppressive effects [36]. However, the actual risk associated with milk intake in terms of T1D development is far from elucidated as conflicting results have been reported [37]. Several studies report that milk intake correlates positively with $\beta$-cell autoimmunity and T1D incidence rates in children $[36,38,39]$, but also studies showing no effect has been published $[37,40]$.

\subsection{Cereals}

Early weaning and introduction of solid foods [41] and especially gluten containing cereals $[42,43]$ has been associated with development of T1D associated autoimmunity, though other studies did not find the same relationship [28]. According to Norris et al. both early (before 3 months of age) and late (after 7 months) introduction to cereals were associated with an increased hazard ratio for developing islet autoimmunity [43], indicating that timing is important possibly due to interference with the developing immune system in the infant. In a more recent study, delaying gluten exposure from 6 months, as officially recommended in Germany, to 12 months did not have any influence on the risk of developing islet autoimmunity at the age of 3 years $[44,45]$. However, in animal models exposure to gluten has been found to have profound impact on T1D incidence. NOD mice fed a gluten-free diet, where cereal based protein have been replaced with meat-based protein, have a 4 -fold lower diabetes incidence (15\% vs. $64 \%$ ) compared to mice fed a standard (gluten-containing) diet [46]. Further, compared to a gluten-free diet (with soya replacing wheat as 
protein source), a wheat-based diet was found to induce a Th1type, proinflammatory cytokine-bias in the gut of NOD mice [47]. Also in fully immune-competent BALB/c-mice a gluten-containing diet (same diet as in [46]) has been found to alter the cytokine-profile of lymphoid Foxp $3^{-}$and Foxp3 ${ }^{+}$regulatory $\mathrm{T}$ cells in a pro-inflammatory direction and in general result in a decreased proportion of $\gamma \delta \mathrm{T}$ cells in lymphoid tissue compared to a glutenfree diet $[48,49]$. Similarly, in diabetes-prone BioBreeding rats (BB-DP) a cereal containing diet induces Th1 cytokine-bias with up-regulation of the proinflammatory cytokine Ifng [50]. Gluten (and cereal) free diets strongly influences GM composition compared to a standard, cereal-based chow diet [51-53] and it can been speculated that the protective effect on T1D development is due to diet-mediated changes of the GM which in turn influence immune system maturation and function, though dietary components themselves probably also play an important role, as a cereal free diet has been found to protect germ free mice against T1D development [50,52]. In an interesting case-study a 6 years old boy newly diagnosed with T1D was administered to a strict gluten-free diet which stabilized HbAc1 and fasting glucose levels within the non-diabetic range without the need for insulin treatment [54]. After having had T1D for 3 years he still does not need insulin regularly.

However, whether it is gluten per se that initiates the process leading to T1D in the animal models (as well as humans?) or whether other cereal (/wheat) dietary components might influence the picture is not fully elucidated. Surprisingly, it has for instance been found, that not only a gluten-free diet but also a diet enriched with purified gluten protects NOD mice against T1D development [55] compared to the standard Altromin diet used in $[46,48,49]$. A recent study on the other hand reported that when purified gluten was supplemented to a gluten-free diet, the T1D protective effect was abolished [52]. The finding that up to $10 \%$ of individuals diagnosed with T1D also have celiac disorders [56] does however indicate that gluten is likely to play a role T1D development, at least in some individuals [54].

\subsection{Other major dietary groups}

The average per capita intake of meat $[39,40]$ and fruit and berry juices [38] has been found to correlate positively with $\beta$-cell autoimmunity. However, a later study could not confirm the association between meat consumption and $\beta$-cell autoimmunity [38] and possibly the associations are confounded by other factors.

\subsection{Vitamin D}

In Europe there is a North-South gradient in T1D incidence, with Finland in the north having the highest incidence worldwide, and more southern regions generally having lower incidence, though with exceptions such as Sardina, where incidence is very high, despite its geographical position in the southern part of Europe $[11,13,57]$. This has been ascribed to many factors including genetics, but also vitamin $\mathrm{D}$ deficiency has been speculated to play a role. The human body is able to synthesize vitamin $\mathrm{D}$, but this requires the exposure of the skin to UV-light from the sun [58], putting the population in countries with only little daylight during winter time at risk of vitamin D deficiency [58]. In vitro vitamin D has been found to protect rat pancreatic islet $\beta$-cell function against interleukin-1 $\beta$-induced inhibition [59] and in vivo administration of high doses of vitamin $\mathrm{D}$ has also been found to protect NOD mice against T1D development, but only if administered throughout life, while administration of vitamin $D$ during pregnancy/lactation and early in life (3-14 weeks of age) had no protective effect [60]. Vitamin D supplementation in early childhood has been associated with significantly lowered T1D incidence
[61] with e.g. Hyppönen et al. reporting that both regular and irregular intake of vitamin D supplementation reduced the T1D incidence with more than a factor 6 among Finnish children. However, it should be noted, that the population living in Russian Karalia neighboring Finland and with the same genetic T1D susceptibility has as mentioned previously approximately one-sixth the risk of developing T1D as Finns, despite the fact that their circulating vitamin D concentrations are almost similar [14,62]. Further, a recent study found no correlation between vitamin D status and increased risk of $\beta$-cell autoimmunity [63] leaving the influence of vitamin D on T1D incidence open for debate.

\subsection{Other food related factors}

Nitrite and nitrate has also been linked to T1D development in several studies $[64,65]$. Nitrate is found in many vegetables and depending on local conditions also in drinking water, while both nitrite and nitrate is found in meat products, such as sausages, where they are used to stabilize color and add an extra barrier towards the growth of Clostridium botulinum [66]. In case-control studies intake of nitrite and nitrate from food and drinking water has been linked to T1D incidence [64,65]. It is not the two compounds themselves that constitute a risk in terms of T1D development, but in the gut they may react with amines and amides in a process mediated by gut microbes and form toxic nitrosamines and nitrosamides $[67,68]$. Also the $\mathrm{pH}$ of drinking water has been directly linked with T1D development in NOD mice, with mice receiving acidified drinking water developing T1D faster and with a significantly higher incidence compared to mice receiving drinking water with a neutral $\mathrm{pH}$ [69].

Food and beverages might also indirectly become sources of pollutants such as the endocrine disruptor bisphenol $\mathrm{A}$, used in food and beverage containers made of polycarbonate plastic. Through leaking from the packaging material food and beverages are the major sources of human exposure to bisphenol A. Though no direct link between bisphenol A exposure and T1D development has been established in humans, bisphenol A exposure has been linked to allergic asthma in children, modulate the immune system in mice models, and both perinatal and postnatal exposure has been shown to accelerate T1D development in NOD mice [70-72].

\section{Exposure to microbial agents}

The intriguing observation that there is an inverse relationship between the incidence of a wide range of infectious diseases (measles, mumps, rheumatic fever etc., incidence all decreasing) and diseases related to immune disorders (asthma, multiple sclerosis, T1D etc., incidence all increasing) led to the development of the so-called hygiene hypothesis $[13,73,74]$, basically stating that due to better hygiene and health care systems we are less exposed to infectious agents, symbiotic microorganisms, parasites and allergens during childhood which influences immune system development leading to among other things an altered Th1/Th2 balance, which again might render us more susceptible to autoimmune diseases [75,76].

The above mentioned 6-fold difference in T1D incidence between Russian Karelia and Finland is one of several examples speaking in favor of environmental factors possibly linked to different hygiene levels and risk of infections playing an important role in T1D development $[13,75]$.

\subsection{Helminths}

Decreasing incidences of helminth infections as a result of better hygiene conditions have been speculated to play a role in the increasing T1D incidence observed worldwide. Gale (2002) argue 
that the decreasing rate of children infected with the pinworm Enterobius vermicularis correlates well with the simultaneously increasing T1D incidence in industrialized countries [77]. In addition to pinworms, also the helminth parasites Heligmosomoides polygyrus, Trichinella spiralis, Litomosoides sigmodontis and Schistosoma mansoni either completely inhibit or significantly slow T1D development and lower incidence in NOD mice [77-80]. In the case of $H$. polygyrus inoculation at 5 weeks of age protected entirely against T1D development, but even inoculation as late as 12 weeks of age significantly delayed onset time and reduced T1D incidence [79]. The protective effect is generally believed to be mediated through a shift in the Th1/Th2-balance, towards a more pronounced Th2-type response and with increased numbers of splenic regulatory T-cells [78-83]. However, recent findings from studies carried out in IL-4 deficient NOD-mice suggest that protection against T1D is independent of a Th2 shift, but requires secretion of the regulatory cytokines IL-10 and TGF- $\beta$ [83,84]. No human studies investigating the potential of using helminths as "vaccines" against T1D development have been published to date, but for inflammatory bowel disease and multiple sclerosis pilot clinical trials have shown promising results $[81,85,86]$. The use of helminths in profylatic treatment of T1D is potentially promising, but not without concerns in terms of possible negative side effects [83]. Helminths cause chronic IgE-mediated activation of basophils and mast cells. In a proof of concept study it has been shown that instead of infecting with live helminths, protection against T1D development in NOD mice can also, at least to some extent be achieved by mimicking helminth infection through injection with anti-FceR1 antibodies binding to the FceR1 IgE receptor on basophils and mast cells thus releasing IL-4 and delaying T1D onset [87] pointing at a strategy for obtaining the protective effect of helminth infections, without the need for infection with actual helminths.

\subsection{Viruses}

Onset of T1D follows a seasonal pattern, with higher onset incidence during Autumn and Winter which already in 1926 led Adams to suspect a viral cause of T1D $[88,89]$. A range of viruses have been implicated in T1D etiology, but in most cases the associations were found to be weak or irreproducible in follow-up studies as recently reviewed [88]. However, in the case of singlestranded RNA enterovirus of the Picornaviridae family, the association between viral infection and T1D incidence seems rather strong. In a recent meta-analysis enterovirus infection was associated with T1D related autoimmunity at an odds ratio of 3.7 and with clinical T1D at an odds ratio of 9.8 [90]. Similarly, a Finnish study has also shown that enteroviral RNA is found in diabetics significantly more frequent than in both celiacs and healthy controls [91]. Further, it was found that the infection was prolonged or persistent in many of the T1D patients and that the infection was associated with gut mucosa inflammation, though a later Italian study was not able to confirm this finding, as they were unable to detect enterovirus in small intestinal biopsy samples from neither T1D patients, nor healthy controls [92]. Also perinatal exposure to enterovirus is possibly a risk factor, as a Swedish study found increased prevalence of enteroviral RNA in the blood of newborns who later developed T1D, while the prevalence of cytomegalovirus (CMV) and parvovirus B19 was similar between newborns who later developed T1D and healthy controls [93]. The presence of enteroviral RNA in blood has been linked with a particular, T1Dassociated genotype of the IFIH1 gene encoding interferon-induced helicase $C$ that senses double-stranded RNA of the Picornavirales virus family including enterovirus [94]. During the first couple of years after birth there is also a high risk of enterovirus exposure with for instance $29 \%$ of a cohort of genetically T1D susceptible
Finnish children aged 2 years or younger being positive [95], but the implications in terms of T1D development (if any) does probably not manifest until later in life, as a German study found no correlation between enterovirus infections during the first year of life and development of islet antibodies [91,96]. Another recent German study showed that also respiratory infections during the first year of life is associated with increased risk of islet antibody sero-conversion [97]. Furthermore, Encephalomyocarditis virus (EMCV), which is a picornavirus, induces fulminant type 1 diabetes in specific inbred strains of mice [98], and milder diabetes in Syrian hamsters [99] and Mongolian gerbils [100].

\subsection{Gut microbiota}

Recent years development within mainly high throughput sequencing technologies have enabled hitherto unseen detailed characterization of the human GM establishing links between GM and a range of disease conditions such as type 2 diabetes [101,102] and autoimmune diseases like atopic dermatitis [103]. The possible involvement of the GM in T1D development is receiving increasing attention and several lines of evidence not only suggest that GM is an important factor in the progression towards T1D, but also that GM manipulation offers possibilities for delaying and perhaps even preventing T1D development [104-106].

The human gastrointestinal (GI) system harbours a complex and dynamic consortium of 10-100 trillion microorganisms encoding as much as 100 -fold more unique genes than the human genome itself. The genetic potential of the microbial inhabitants of our GI-tract is consequently massive and strongly influences human health and disease [107]. GM composition and development is determined in a delicate interplay between genetic and environmental factors [108-110] that we are only beginning to understand. In utero the GI tract is sterile, but during and after birth it is rapidly colonized. Mode of birth (vaginal birth vs. caesarean section (CS)) and feeding (breast feeding vs. bottle feeding) are both important drivers of GM development [108,109,111-114]. Initially the GM is dominated by oxygen tolerant species (e.g. staphylococci and Enterobacteriaceae), before obligate anaerobes (bifidobacteria, clostridia, eubacteria) take over and after a couple of years the child GM tend to approach the composition of the adult gut $[108,109,115,116]$.

Several studies report that the GM differs between children with $\beta$-cell autoimmunity [117] or T1D and healthy, age and genotypically matched controls [118-121]. A recent German study comparing GM development in genetically at risk children up to the age of 3 years rather than identifying a particular GM compositional fingerprint associated with anti-islet cell autoimmunity, instead identified substantial alterations in microbial interaction networks between anti-islet antibody positive children and genetically and age-matched healthy controls [122]. In all cases the investigated cohorts are rather small (between 3 and 22 diabetics/individuals with $\beta$-cell autoimmunity) and even though they all provide valuable findings larger cohort studies investigating the link between GM and T1D development are highly needed. Several studies $[117,120,121]$ indicate that $\beta$-cell autoimmunity and T1D is associated with a lower overall GM diversity, though in [122] no significant difference in GM diversity was found between children who developed anti-islet cell autoimmunity and healthy controls. Low GM diversity has also been linked to atopic dermatitis [103], another autoimmune condition, and low overall GM genetic diversity ("low gene count") has been linked to metabolic syndrome [123]. Birth by CS is associated with an increased risk of T1D development [124]. Recently, birth by CS has been linked with reduced GM diversity, and especially within the Bacteroidetes phylum infants born by CS had significantly lower diversity compared to infants born vaginally. Further, the 
infants born by CS had significantly lower blood concentrations of the Th1 associated chemokines CXCL10 and CXCL11, while no significant differences where observed for the Th2 associated chemokines CCL17 and CCL22. Differences in GM composition between children born vaginally and by CS has been shown to persist up 7 years of age [125].

In the investigated Finnish and Spanish co-horts the abundance of Bacteroides is in general higher in cases compared to controls, with for instance Bacteroides ovatus and Bacteroides uniformis being associated with autoimmunity, while Bacteroides fragilis on the other hand seems to play a protective role $[117,118,120,121]$. However, no differences in Bacteroides abundance between children who developed anti-islet cell autoimmunity and healthy controls were observed in a recent German study [122]. Bifidobacteria, butyrate producers such as Faecalibacterium and Roseburia and mucin degraders like Prevotella and Akkermansia all constitute a larger proportion of the GM in healthy controls compared to cases indicating that they might play a protective role $[117,118,120$, $121,126,127]$, though [120] could not confirm the tendency for Prevotella and [122] as mentioned above rather than identifying particular taxonomic units differing between children who developed anti-islet cell autoimmunity and healthy controls, instead identified substantial microbial interaction network disturbances in the anti-islet antibody positive children. The reason behind the possibly protective role of bifidobacteria is not clear, but de Goffau et al. [117] suggest that they reduce growth of e.g. Bacteroides members and/or reduce their translocation over the epithelium reducing inflammation. Butyrate is an inducer of mucin production [128,129]. In line with this, Brown et al. [118] suggests, that a GM rich in butyrate producers leads to increased mucin production, more tight junctions and increased gut integrity. The increased mucin production then creates a favorable niche for mucin degraders (Prevotella, Akkermansia), and [118] suggest that mucin degraders possibly can be used as indicators of gut integrity. In this context it is interesting to note, that even though not reported as significantly different, phylum Verrucomicrobia (of which Akkermansia muciniphila is the only known gut microbiota associated member [130]) has been found to be more abundant in children that did not develop anti-islet autoimmunity, compared to those that did, at all time points from 6 months of age to 3 years [122]. Metabolome studies support, that GM differs between T1D patients and healthy controls, as a range of metabolites of gut microbial metabolism differs between the 2 groups [131,132].

Evidence from animal models supports that GM plays an important role in T1D development. Bio-breeding diabetes-prone (BBDR) rats have a GM significantly different from the GM of bio-breeding diabetes-resistant (BB-DR) rats, with the BB-DP rats having lower GM diversity, especially later in life (70 days), more Bacteroides and less Bifidobacterium compared to BB-DR rats [133], which by large corresponds well with the picture seen in humans $[117,118,120]$. Similarly, NOD mice that develop diabetes have a different GM already at weaning compared to NOD mice that do not develop T1D. This difference in GM composition persists into adulthood, where NOD mice that has developed T1D has a GM different from NOD mice that had not developed T1D up to 30 weeks of age [51 and own data, submitted for publication].

In some cases germ-free rearing has been found to exacerbate T1D development in NOD mice, but newer studies report divergent results. According to King and Sarvetnick [134] do germ-free mice not have higher T1D incidence compared to conventional mice, but a restricted gut microbiota offers some protection. Alam et al. [135] report that diabetes develops with equal incidence under both germ-free and specific pathogen free (SPF) conditions, but with significantly higher insulitis scores under germ-free conditions. The lacking GM results in an altered immune regulation in the colon, the mesenteric and the pancreatic lymph nodes with increased levels of IL17 and less FoxP3 cells which may explain the higher insulitis scores [135].

Wen et al. [136] showed that a specific protein, MyD88, involved in recognising microbial stimuli in the gut is essential for T1D progression in NOD mice. MyD88-knockout NOD mice were almost completely protected from developing T1D, whereas heterozygous MyD88 $\mathrm{KO} /+^{+}$NOD mice developed T1D. Interestingly, when reared under germ-free conditions, the MyD88-knockout NOD mice develops robust insulitis, while colonization of the germ-free MyD88-knockout mice attenuated T1D development. In a recent study it was found that not only MyD88, but also TLR3 is critical for T1D development in the RIP-B7.1 diabetes mouse model, confirming the important role of receptors recognising microbial stimuli in the gut [137].

T1D incidence in NOD mice has a strong gender bias, with female mice having higher incidence compared to male mice $[138,139]$. At weaning the male and female GM does not differ, but when the mice reach puberty, the GM and metabolome differs between sexes $[138,139]$. SPF male mice had significantly higher testosterone levels compared to SPF female mice, but when reared under germ-free conditions, male mice had comparable lower and female mice higher testosterone levels, indicating that a "sex specific" GM influences testosterone levels [139]. Transfer of adult male GM to young females altered the GM of the recipients, elevated testosterone levels, changed the metabolome and conferred protection against T1D [139]. Further, if castrated, the male GM does not differ from the female mice and their insulitis score is comparable to female mice [138]. Yurkovetskiy et al. [138] suggests a positive feedback mechanism, where hormones influence GM that again influence the hormone balance; a hypothesis overall in agreement with the finding in [139]. Also in adult humans, gender specific differences in blood metabolome has been identified [140] and a range of autoimmune diseases has a gender bias towards woman having higher incidence, but not in the case of T1D, where men and woman have approximately the same risk (with males even having a slightly higher risk in adulthood) [141]. Nevertheless, the findings in $[138,139]$ underline that GM strongly influences host and T1D development and that disease development can be prevented or at least postponed by GM manipulation.

The influence of GM on T1D is further augmented by the finding that the presence or absence of segmented filamentous bacteria (SFB) in the gut has profound impact in T1D incidence in NOD mice [142]. SFB strongly influence host immune system development influencing T helper cell maturation and inducing intestinal Th17 cells [143-145] and has been found to be associated with protection against T1D development in female NOD mice (male NOD mice had low incidence regardless of SFB status) [142]. The exact mechanism behind the possible protective effect of SFB on T1D development in NOD mice has not been elucidated but Kriegel et al. [142] hypothesize that possibly the SFB induces a robust population of intestinal Th17 cells protecting against islet destruction by inhibiting the Th1-response, though this notion remains debateable [146]. However, in another study female NOD mice mono-colonized with SFB had a similar diabetes incidence as the germ-free mice [138]. No matter the exact role of SFB in protecting female NOD mice against T1D it should be noted that different vendors and experimental animal facilities differs with respect to gut microbiota composition, including SFB status [142,145], which probably explain the large differences in NOD mice T1D incidence occasionally reported.

\subsection{Gut microbiota manipulation}

Antibiotic treatment reduce diabetes incidence in both BB-DP rats and NOD mice $[104,147,148]$. In BB-DP rats, treatment with 
a mixture of sulfamethoxazole, trimethoprim and colistine sulfate from weaning significantly reduced T1D incidence [147]. Exchanging the conventional plant-based diet, with a diet where hydrolysed casein was the sole protein source also offered some protection and if the hydrolysed casein diet was combined with antibiotic treatment no rats developed T1D [147]. A later study in NOD mice underlines that timing is important, as treatment with vancomycin from birth to weaning significantly reduced T1D incidence, while treatment only during adulthood did not offer the same protection [104]. Vancomycin treatment resulted in a switch from a GM dominated by Firmicutes and Bacteroidetes to a GM dominated by A. muciniphila (Verrucomicrobia) and to a lesser extent Proteobacteria [104]. The mechanism behind the protective effect of vancomycin treatment is not known, but it can be speculated, that the abundance of the mucin degrader $A$. muciniphila leads to an increased metabolisation of mucin, which might increase the possibility for other Gram-negative bacteria (like Proteobacteria) or ligands therefrom (e.g. lipopolysaccharides, LPS) to get in contact with intestinal immune cells at a critical stage during immune system maturation stimulating e.g. TLR-4, known to play a role in protection against T1D development [104], though other mechanisms are also possible. Humans diagnosed with T1D have a slightly decreased natural killer cell expression of NKG2D and also NOD mice have an altered natural killer cell NKG2D expression profile $[149,150]$. Intestinal epithelial cell expression of NKG2D has to date not been implicated in T1D etiology, but given that a receptor like My88D involved in recognition of intestinal microbial stimuli has a profound impact on T1D development in NOD mice, it is of interest, that vancomycin treatment has been found to decrease the expression of NKG2D ligands on intestinal epithelial cells [151]. Interestingly, propagation of $A$. muciniphila and decreased NKG2D ligand expression could also be achieved through feeding with dietary xylosaccharides as well, showing that also through a dietary intervention is it possible to influence gut epithelial ligand expression and increase A. muciniphila in the GI tract [151].

Recently, Sofi et al. [69] showed that female NOD mice receiving acidified water ( $\mathrm{pH}$ 3.0-3.2) compared to neutral water ( $\mathrm{pH} 7.0-$ 7.2) markedly change GM composition and increase T1D incidence. Switching from acidified water to neutral water lowered abundance of Bacteroides but where in general associated with an increase in GM diversity, which corresponds well with previous findings indicating that low GM diversity is associated with autoimmunity and T1D $[117,120,121]$. Colonisation of mice receiving acidified drinking water with SFB lowered T1D incidence, while SFB colonisation did not influence T1D incidence in mice receiving neutral $\mathrm{pH}$ water [69], indicating that SFB influences T1D incidence in NOD mice, but only in collaboration with specific gut microbiotas.

Switching from a conventional chow-based diet to a gluten-free diet significantly reduces T1D-incidence in NOD-mice and is associated with pronounced GM differences between the 2 feeding regimes [46,51,52], with the gluten-free diet promoting $A$. muciniphila, while the gluten-containing chows were associated with increased Tannerella, Barnesiella and perhaps more surprisingly bifidobacteria [52], which also contradicts findings from our laboratory, showing that a gluten-free diet is associated with higher GM prevalence of bifidobacteria (own results, submitted for publication). Similar results have been obtained in BB-DP rats, where feeding a diet with hydrolysed casein as protein source resulted in significantly lower T1D incidence in both germ-free and SPF animals, compared to being fed a cereal-based, gluten-containing diet [50]. In a recent study, we show that maternal feeding with a gluten-free diet significantly reduces T1D incidence in the offspring (NOD mice). Pregnant NOD mice were fed either a gluten-free or a standard chow diet, until the pups were weaned to the standard diet - meaning that the pups were exposed to the effect of a gluten-free diet via cohousing with the mother. This resulted in pronounced GM differences between the 2 feeding regimes (also in the pups at weaning), with the gluten-free GM being characterized by increased Akkermansia, Proteobacteria, and TM7. Pancreatic FoxP3 regulatory $\mathrm{T}$ cells were increased in gluten-free fed offspring, while intestinal gene expression of proinflammatory cytokines was reduced. An increased proportion of pancreatic T cells expressing the mucosal integrin $\alpha 4 \beta 7$ indicates the T1D protective mechanism involve increased transport of gut-primed immune cells to the pancreas [53]. Whether the protective effect of a gluten-free diet is transferable to humans is far from given, as the importance of gluten in human T1D etiology is still up for debate [43-45]. But a case report indicating that switching to a gluten-free diet as diabetes is diagnosed at least delays and possibly even prevents disease progression [see 54 and discussion above] warrants further studies. Furthermore, the findings that probiotic administration [152] and GM manipulation through diet [50,52], pH of drinking water [69], and antibiotics [104] prevents or delays T1D onset in experimental animals point towards the gut as a promising target for T1D prevention in individuals genetically at risk.

\section{Conclusion}

The drivers of T1D development are far from identified, but a range of candidates have been identified, including dietary habits (breast feeding vs. infant formula, highly hydrolysed infant formula vs. conventional infant formula, early/late exposure to gluten, vitamin D deficiency etc.), exposure to certain viruses and helminths. What unifies these candidates (with the exception of vita$\min \mathrm{D}$ ) is that their effect one way or the other is mediated via the gut. The importance of our GI system in T1D etiology is further augmented by the differences in GM composition and gut microbial networks observed between individuals diagnosed with T1D/ $\beta$-cell autoimmunity and healthy controls and perhaps even more importantly the increasing number of animal studies providing proof of concept of how GM manipulation can be used to prevent or reduce T1D incidence. Time is up for carefully designed, longitudinal studies with adequate power first establishing in greater detail how GM, metabolome, immune system development, and autoimmunity/T1D are connected and whether "early warning GM patterns" can be identified. In individuals at risk, it then becomes highly relevant to develop tools for directing the GM in a desired direction away from the "T1D risk profile" using appropriate means, be it dietary intervention, targeted use of antibiotics or possibly by using bacteriocin-producing bacteria [153] or phage cocktails [154] targeting unwanted GM members.

\section{Conflict of interest}

The authors declare no conflict of interest.

\section{Acknowledgements}

Łukasz Krych is supported by Center for Applied Laboratory Animal Research (www.calar.dk) and the Chemometric Analysis Centre (www.chance.life.ku.dk). Camilla H.F. Hansen is funded by the Carlsberg Foundation.

\section{References}

[1] Van Belle, T.L., Coppieters, K.T. and Von Herrath, M.G. (2011) Type 1 diabetes: etiology, immunology, and therapeutic strategies. Physiol. Rev. 91, 79-118.

[2] Melendez-Ramirez, L.Y., Richards, R.J. and Cefalu, W.T. (2010) Complications of type 1 diabetes. Endocrinol. Metabol. Clin. North Am. 39, 625-640.

[3] Dahlquist, G. and Kallen, B. (2005) Mortality in childhood-onset type 1 diabetes. Diabetes Care 28, 2384-2387. 
[4] Patterson, C.C., Dahlquist, G.G., Gyurus, E., Green, A. and Soltész, G. (2009) Incidence trends for childhood type 1 diabetes in Europe during 1989-2003 and predicted new cases 2005-20: a multicentre prospective registration study. Lancet 373, 2027-2033.

[5] Skrivarhaug, T., Stene, L., Drivvoll, A., Ström, H. and Joner, G. (2014) Incidence of type 1 diabetes in Norway among children aged 14-áyears between 1989 and 2012: has the incidence stopped rising? Results from the Norwegian Childhood Diabetes Registry. Diabetologia 57, 57-62.

[6] Berhan, Y., Waernbaum, I., Lind, T., Mollsten, A. and Dahlquist, G. (2011) Thirty years of prospective nationwide incidence of childhood type 1 diabetes the accelerating increase by time tends to level off in Sweden. Diabetes 60, $577-581$.

[7] Barker, J.M., Triolo, T.M., Aly, T.A., Baschal, E.E., Babu, S.R., Kretowski, A., Rewers, M.J. and Eisenbarth, G.S. (2008) Two single nucleotide polymorphisms identify the highest-risk diabetes HLA genotype: potential for rapid screening. Diabetes 57, 3152-3155.

[8] Nerup, J., Platz, P., Andersen, O.O., Christy, M., Lyngsoe, J., Poulsen, J.E., Ryder, L.P., Thomsen, M., Nielsen, L.S. and Svejgaard, A. (1974) Hl-A antigens and diabetes-mellitus. Lancet 304, 864-866.

[9] Ziegler, A.G. and Nepom, G.T. (2010) Prediction and pathogenesis in type 1 diabetes. Immunity 32, 468-478.

[10] Kyvik, K.O., Green, A. and Beck-Nielsen, H. (1995) Concordance rates of insulin dependent diabetes mellitus: a population based study of young Danish Twins. BMJ 311, 913-917.

[11] Karvonen, M., Viik-Kajander, M., Moltchanova, E., Libman, I., LaPorte, R. and Tuomilehto, J. (2000) Incidence of childhood type 1 diabetes worldwide. diabetes mondiale (DiaMond) project group. Diabetes Care 23, 1516-1526.

[12] Atkinson, M.A. (2012) The pathogenesis and natural history of type 1 diabetes. Cold Spring Harb. Perspect. Med. 2, a007641.

[13] Bach, J.F. and Chatenoud, L. (2012) The hygiene hypothesis: an explanation for the increased frequency of insulin-dependent diabetes. Cold Spring Harb. Perspect. Med. 4, a007799.

[14] Kondrashova, A., Reunanen, A., Romanov, A., Karvonen, A., Viskari, H. Vesikari, T., Ilonen, J., Knip, M. and Hyoty, H. (2005) A six-fold gradient in the incidence of type 1 diabetes at the eastern border of Finland. Ann. Med. 37, 67-72.

[15] Knip, M. and Simell, O. (2012) Environmental triggers of type 1 diabetes. Cold Spring Harb. Perspect. Med. 2, a007690.

[16] Oilinki, T., Otonkoski, T., Ilonen, J., Knip, M. and Miettinen, P.J. (2012) Prevalence and characteristics of diabetes among Somali children and adolescents living in Helsinki, Finland. Pediatr. Diabetes 13, 176-180.

[17] Ji, J.G., Hemminki, K., Sundquist, J. and Sundquist, K. (2010) Ethnic differences in incidence of type 1 diabetes among second-generation immigrants and adoptees from abroad. J. Clin. Endocrinol. Metab. 95, 847-850.

[18] Hussen, H.I., Persson, M. and Moradi, T. (2013) The trends and the risk of type 1 diabetes over the past 40 years: an analysis by birth cohorts and by parental migration background in Sweden. BMJ Open 3, e003418.

[19] Soderstrom, U., Aman, J. and Hjern, A. (2012) Being born in Sweden increases the risk for type 1 diabetes - a study of migration of children to Sweden as a natural experiment. Acta Paediatr. 101, 73-77.

[20] Raymond, N.T., Jones, J.R., Swift, P.G.F., Davies, M.J., Lawrence, I.G., McNally, P.G., Burden, M.L., Gregory, R., Burden, A.C. and Botha, J.L. (2001) Comparative incidence of type I diabetes in children aged under 15 years from South Asian and White or Other ethnic backgrounds in Leicestershire, UK, 1989 to 1998. Diabetologia 44, B32-B36.

[21] Virtanen, S.M. and Knip, M. (2003) Nutritional risk predictors of beta-cell autoimmunity and type 1 diabetes at a young age. Am. J. Clin. Nutr. 78, 10531067.

[22] Virtanen, S.M., Rasanen, L., Ylonen, K., Aro, A., Clayton, D., Langholz, B., Pitkaniemi, J., Savilahti, E., Lounamaa, R., Tuomilehto, J., Akerblom, H.K., Toivanen, L., Kaprio, E.A., Pitkaniemi, J., Virtala, E., Fagerlund, A., Vonflittner, M., Gustafsson, B., Haggqvist, C., Hakulinen, A., Herva, L., Hiltunen, P., Huhtamaki, T., Huttunen, N.P., Huupponen, T., Hyttinen, M., Joki, T., Jokisalo, R., Kaar, M.L., Kallio, S., Kaprio, E.A., Kaski, U., Knip, M., Laine, L., Lappalainen, J., Maenpaa, J., Makela, A.L., Niemi, K., Niiranen, A., Ojajarvi, P., Otonkoski, T. Pihlajamaki, K., Pontynen, S., Rajantie, J., Sankala, J., Schumacher, J., Sillanpaa, M., Stahlberg, M.R., Stahlmann, C.H., Uotila, T., Vare, M. and Varimo, P. (1993) Early introduction of dairy-products associated with increased risk of IDDM in Finnish children. Diabetes 42, 1786-1790.

[23] Rosenbauer, J., Herzig, P. and Giani, G. (2008) Early infant feeding and risk of type 1 diabetes mellitus - a nationwide population-based case-control study in pre-school children. Diabetes Metab. Rev. 24, 211-222.

[24] Rosenbauer, J., Herzig, P., Kaiser, P. and Giani, G. (2007) Early nutrition and risk of type 1 diabeties mellitus - a nationwide case-control study in preschool children. Exp. Clin. Endocrinol. Diabetes 115, 502-508.

[25] Robertson, L. and Harrild, K. (2010) Maternal and neonatal risk factors for childhood type 1 diabetes: a matched case-control study. BMC Publ. Health 10, 281, http://dx.doi.org/10.1186/1471-2458-10-281.

[26] Cardwell, C.R., Stene, L.C., Ludvigsson, J., Rosenbauer, J., Cinek, O., Svensson, J. Perez-Bravo, F., Memon, A., Gimeno, S.G., Wadsworth, E.J.K., Strotmeyer, E.S., Goldacre, M.J., Radon, K., Chuang, L.M., Parslow, R.C., Chetwynd, A., Karavanaki, K., Brigis, G., Pozzilli, P., Urbonaite, B., Schober, E., Devoti, G., Sipetic, S., Joner, G., Ionescu-Tirgoviste, C., de Beaufort, C.E., Harrild, K., Benson, V., Savilahti, E., Ponsonby, A.L., Salem, M., Rabiei, S. and Patterson, C.C. (2012) Breast-feeding and childhood-onset type 1 diabetes a pooled analysis of individual participant data from 43 observational studies. Diabetes Care 35, 2215-2225.

[27] Dahlquist, G., Savilahti, E. and Landinolsson, M. (1992) An increased level of antibodies to beta-lactoglobulin is a risk determinant for early-onset type-1 (insulin-dependent) diabetes-mellitus independent of islet cell antibodies and early introduction of cows milk. Diabetologia 35, 980-984.

[28] Savilahti, E. and Saarinen, K.M. (2009) Early infant feeding and type 1 diabetes. Eur. J. Nutr. 48, 243-249.

[29] Wadsworth, E.J.K., Shield, J.P.H., Hunt, L.P. and Baum, J.D. (1997) A casecontrol study of environmental factors associated with diabetes in the under 5s. Diabetic Med. 14, 390-396.

[30] Emani, R., Asghar, M.N., Toivonen, R., Lauren, L., Soderstrom, M., Toivola, D.M., van Tol, E.A.F. and Hanninen, A. (2013) Casein hydrolysate diet controls intestinal $\mathrm{T}$ cell activation, free radical production and microbial colonisation in NOD mice. Diabetologia 56, 1781-1791.

[31] Driver, J.P., Serreze, D.V. and Chen, Y.G. (2011) Mouse models for the study of autoimmune type 1 diabetes: a NOD to similarities and differences to human disease. Semin. Immunopathol. 33, 67-87.

[32] Knip, M., Virtanen, S.M., Becker, D., Dupre, J., Krischer, J.P. and Akerblom, H.K (2011) Early feeding and risk of type 1 diabetes: experiences from the Trial to Reduce Insulin-dependent diabetes mellitus in the Genetically at Risk (TRIGR). Am. J. Clin. Nutr. 94, 1814S-1820S.

[33] Vaarala, O., Ilonen, J., Ruohtula, T., Pesola, J., Virtanen, S.M., Harkonen, T. Koski, M., Kallioinen, H., Tossavainen, O., Poussa, T., Jarvenpaa, A.L. Komulainen, J., Lounamaa, R., Akerblom, H.K. and Knip, M. (2012) Removal of bovine insulin from cow's milk formula and early initiation of beta-cell autoimmunity in the FINDIA pilot study. Arch. Pediatr. Adolesc. Med. 166 608-614.

[34] Virtanen, S.M., Laara, E., Hypponen, E., Reijonen, H., Rasanen, L., Aro, A., Knip, M., Ilonen, J. and Akerblom, H.K. (2000) Cow's milk consumption, HLA-DQB1 genotype, and type 1 diabetes - a nested case-control study of siblings of children with diabetes. Diabetes 49, 912-917.

[35] Elliott, R.B., Reddy, S.N., Bibby, N.J. and Kida, K. (1988) Dietary prevention of diabetes in the non-obese diabetic mouse. Diabetologia 31, 62-64.

[36] Elliott, R.B., Harris, D.P., Hill, J.P., Bibby, N.J. and Wasmuth, H.E. (1999) Type (insulin-dependent) diabetes mellitus and cow milk: casein variant consumption. Diabetologia 42, 292-296.

[37] Merriman, T.R. (2009) Type 1 diabetes, the A1 milk hypothesis and vitamin D deficiency. Diabetes Res. Clin. Prac. 83, 149-156.

[38] Virtanen, S.M., Nevalainen, J., Kronberg-Kippilä, C., Ahonen, S., Tapanainen, H., Uusitalo, L., Takkinen, H.M., Niinistö, S., Ovaskainen, M.L., Kenward, M.G., Veijola, R., Ilonen, J., Simell, O. and Knip, M. (2012) Food consumption and advanced Beta-cell autoimmunity in young children with HLA-conferred susceptibility to type 1 diabetes: a nested case-control design. Am. J. Clin. Nutr. 95, 471-478.

[39] Muntoni, S., Cocco, P., Aru, G., Cucca, F. and Muntoni, S. (2000) Nutritional factors and worldwide incidence of childhood type 1 diabetes. Am. J. Clin. Nutr. 71, 1525-1529.

[40] Muntoni, S. and Muntoni, S. (2006) Epidemiological association between some dietary habits and the increasing incidence of type 1 diabetes worldwide. Ann. Nutr. Metabol. 50, 11-19.

[41] PerezBravo, F., Carrasco, E., GutierrezLopez, M.D., Martinez, M.T., Lopez, G. and delosRios, M.G. (1996) Genetic predisposition and environmental factors leading to the development of insulin-dependent diabetes mellitus in Chilean children. J. Mol. Med. 74, 105-109.

[42] Ziegler, A.G., Schmid, S., Huber, D., Hummel, M. and Bonifacio, E. (2003) Early infant feeding and risk of developing type 1 diabetes-associated autoantibodies. JAMA 290, 1721-1728.

[43] Norris, J.M., Barriga, K., Klingensmith, G., Hoffman, M., Eisenbarth, G.S., Erlich, H.A. and Rewers, M. (2003) Timing of initial cereal exposure in infancy and risk of islet autoimmunity. JAMA 290, 1713-1720.

[44] Hummel, S. and Ziegler, A.G. (2011) Early determinants of type 1 diabetes: experience from the BABYDIAB and BABYDIET studies. Am. J. Clin. Nutr. 94, 1821S-1823S.

[45] Hummel, S., Pfluger, M., Hummel, M., Bonifacio, E. and Ziegler, A.G. (2011) Primary dietary intervention study to reduce the risk of islet autoimmunity in children at increased risk for type 1 diabetes the BABYDIET study. Diabetes Care 34, 1301-1305.

[46] Funda, D.P., Kaas, A., Bock, H., Tlaskalova-Hogenova, H. and Buschard, K. (1999) Gluten-free diet prevents diabetes in NOD mice. Diabetes Metab. Res. Rev. 15, 323-327.

[47] Flohe, S.B., Wasmuth, H.E., Kerad, J.B., Beales, P.E., Pozzilli, P., Elliott, R.B., Hill, J.P., Scott, F.W. and Kolb, H. (2003) A wheat-based, diabetes-promoting diet induces a Th1-type cytokine bias in the gut of NOD mice. Cytokine 21, 149154.

[48] Antvorskov, J.C., Fundova, P., Buschard, K. and Funda, D.P. (2012) Dietary gluten alters the balance of proinflammatory and anti-inflammatory cytokines in T cells of BALB/c mice. Immunology (UK) 138, 23-33.

[49] Antvorskov, J.C., Fundova, P., Buschard, K. and Funda, D.P. (2012) Impact of dietary gluten on regulatory T cells and Th17 cells in BALB/c mice. PLoS ONE 7, e33315.

[50] Patrick, C., Wang, G.S., Lefebvre, D.E., Crookshank, J.A., Sonier, B., Eberhard, C. Mojibian, M., Kennedy, C.R., Brooks, S.P.J., Kalmokoff, M.L., Maglio, M., Troncone, R., Poussier, P. and Scott, F.W. (2013) Promotion of autoimmune diabetes by cereal diet in the presence or absence of microbes associated 
with gut immune activation, regulatory imbalance, and altered cathelicidin antimicrobial peptide. Diabetes 62, 2036-2047.

[51] Hansen, A.K., Ling, F., Kaas, A., Funda, D.P., Farlov, H. and Buschard, K. (2006) Diabetes preventive gluten-free diet decreases the number of caecal bacteria in non-obese diabetic mice. Diabetes Metab. Res. Rev. 22, 220-225.

[52] Marietta, E.V., Gomez, A.M., Yeoman, C., Tilahun, A.Y., Clark, C.R., Luckey, D.H., Murray, J.A., White, B.A., Kudva, Y.C. and Rajagopalan, G. (2013) Low incidence of spontaneous type 1 diabetes in nonobese diabetic mice raised on gluten-free diets is associated with changes in the intestinal microbiome. PLOS ONE 8.

[53] Hansen, C.H.F., Krych, L., Buschard, K., Metzdorff, S.B., Nellemand, C.N. Hansen, L.H., Nielsen, D.S., Frøkiær, H., Skov, S. and Hansen, A.K. (2014) A maternal gluten free diet reduces inflammation and diabetes incidence in the offspring of NOD mice. Diabetes, http://dx.doi.org/10.2337/db13-1612.

[54] Sildorf, S.M., Fredheim, S., Svensson, J. and Buschard, K. (2012) Remission without insulin therapy on gluten-free diet in a 6-year old boy with type 1 diabetes mellitus. BMJ Case Reports, http://dx.doi.org/10.1136/ bcr.02.2012.5878.

[55] Funda, D.P., Kaas, A., Tlaskalova-Hogenova, H. and Buschard, K. (2008) Gluten-free but also gluten-enriched (gluten+) diet prevent diabetes in NOD mice; the gluten enigma in type 1 diabetes. Diabetes Metab. Res. Rev. 24, 5963.

[56] Cosnes, J., Cellier, C., Viola, S., Colombel, J.F., Michaud, L., Sarles, J., Hugot, J.P., Ginies, J.L., Dabadie, A., Mouterde, O., Allez, M. and Nion-Larmurier, I. (2008) Incidence of autoimmune diseases in celiac disease: protective effect of the gluten-free diet. Clin. Gastroenterol. Hepatol. 6, 753-758.

[57] Atkinson, M.A., Eisenbarth, G.S. and Michels, A.W. (2014) Type 1 diabetes. Lancet 383, 69-82.

[58] Tsiaras, W.G. and Weinstock, M.A. (2011) Factors influencing vitamin D status. Acta Derm. Venereol. 91, 115-124.

[59] Sandler, S., Buschard, K. and Bendtzen, K. (1994) Effects of 1,25dihydroxyvitamin D-3 and the analogs Mc903 and Kh1060 on interleukin1-beta-induced inhibition of rat pancreatic-islet beta-cell function in vitro. Immunol. Lett. 41, 73-77.

[60] Takiishi, T., Ding, L., Baeke, F., Spagnuolo, I., Sebastiani, G., Laureys, J. Verstuyf, A., Carmeliet, G., Dotta, F., Van Belle, T.L., Gysemans, C. and Mathieu, C. (2014) Dietary supplementation with high doses of regular vitamin D3 safely reduces diabetes incidence in nod mice when given early and longterm. Diabetes, http://dx.doi.org/10.2337/db13-1559.

[61] Hyppönen, E., Läärä, E., Reunanen, A., Järvelin, M.R. and Virtanen, S.M. (2001) Intake of vitamin $\mathrm{D}$ and risk of type 1 diabetes: a birth-cohort study. Lancet 358, 1500-1503.

[62] Viskari, H., Kondrashova, A., Koskela, P., Knip, M. and Hyöty, H. (2006) Circulating vitamin D concentrations in two neighboring populations with markedly different incidence of type 1 diabetes. Diabetes Care 29, 14581459.

[63] Simpson, M., Brady, H., Yin, X., Seifert, J., Barriga, K., Hoffman, M., Bugawan, T., Baron, A.E., Sokol, R., Eisenbarth, G., Erlich, H., Rewers, M. and Norris, J. (2011) No association of vitamin D intake or 25-hydroxyvitamin D levels in childhood with risk of islet autoimmunity and type 1 diabetes: the Diabetes Autoimmunity Study in the Young (DAISY). Diabetologia 54, 2779-2788.

[64] Dahlquist, G.G., Blom, L.G., Persson, L.A., Sandstrom, A.I.M. and Wall, S.G.I. (1990) Dietary factors and the risk of developing insulin-dependent diabetes in childhood. BMJ 300, 1302-1306.

[65] Virtanen, S.M., Jaakkola, L., Rasanen, L., Ylonen, K., Aro, A., Lounamaa, R. Akerblom, H.K., Tuomilehto, J., Akerblom, H.K., Toivanen, L., Kaprio, E.A. Pitkaniemi, J., Virtala, E., Fagerlund, A., Vonflittner, M., Gustafsson, B. Haggqvist, C., Hakulinen, A., Herva, L., Hiltunen, P., Huhtamaki, T., Huttunen, N.P., Huupponen, T., Hyttinen, M., Joki, T., Jokisalo, R., Kaar, M.L., Kallio, S., Kaprio, E.A., Kaski, U., Knip, M., Laine, L., Lappalainen, J., Maenpaa, J., Makela, A.L., Niemi, K., Niiranen, A., Ojajarvi, P., Otonkoski, T., Pihlajamaki, K. Pontynen, S., Rajantie, J., Sakala, J., Schumacher, J., Sillanpaa, M., Stahlberg M.R., Strahlmann, C.H., Toivanen, L., Uotila, T., Vare, M. and Varimo, P. (1994) Nitrate and nitrite intake and the risk for type-1 diabetes in finnish children. Diabetic Med. 11, 656-662.

[66] Adams, M.R. and Moss, M.O. (2008) Food Microbiology, 3 edn, RSC Publishing, Cambridge.

[67] Lundberg, J.O. and Weitzberg, E. (2013) Biology of nitrogen oxides in the gastrointestinal tract. Gut 62, 616-629.

[68] Engemann, A., Focke, C. and Humpf, H.U. (2013) Intestinal formation of Nnitroso compounds in the pig cecum model. J Agric. Food Chem. 61, 9981005.

[69] Sofi, M.H., Gudi, R., Karumuthil-Melethil, S., Perez, N., Johnson, B.M. and Vasu, C. (2014) PH of drinking water influences the composition of gut microbiome and type 1 diabetes incidence. Diabetes 63, 632-644.

[70] Bodin, J., Bølling, A.K., Becher, R., Kuper, F., Løvik, M. and Nygaard, U.C. (2014) Transmaternal bisphenol a exposure accelerates diabetes type 1 development in NOD mice. Toxicol. Sci., http://dx.doi.org/10.1093/toxsci/ kft242.

[71] Bodin, J., Bølling, A.K., Samuelsen, M., Becher, R., Løvik, M. and Nygaard, U.C. (2013) Long-term bisphenol A exposure accelerates insulitis development in diabetes-prone NOD mice. Immunopharmacol. Immunotoxicol. 35, 349-358.

[72] Midoro-Horiuti, T., Tiwari, R., Watson, C.S. and Goldblum, R.M. (2010) Maternal bisphenol a exposure promotes the development of experimental asthma in mouse pups. Environ. Health Perspect. 118, 273-277.
[73] Bach, J.F. (2002) The effect of infections on susceptibility to autoimmune and allergic diseases. New Engl. J. Med. 347, 911-920.

[74] Strachan, D.P. (1989) Hay fever, hygiene, and household size. Br. Med. J. 299, 1259-1260.

[75] Kondrashova, A., Seiskari, T., Ilonen, J., Knip, M. and Hyöty, H. (2013) The "Hygiene hypothesis" and the sharp gradient in the incidence of autoimmune and allergic diseases between Russian Karelia and Finland. APMIS 121, 478493.

[76] Rook, G. (2012) Hygiene hypothesis and autoimmune diseases. Clin. Rev. Allergy Immunol. 42, 5-15.

[77] Gale, E. (2002) A missing link in the hygiene hypothesis? Diabetologia 45, 588-594.

[78] Cooke, A., Tonks, P., Jones, F.M., O'Shea, H., Hutchings, P., Fulford, A.J.C. and Dunne, D.W. (1999) Infection with Schistosoma mansoni prevents insulin dependent diabetes mellitus in non-obese diabetic mice. Parasite Immunol. 21, 169-176.

[79] Liu, Q., Sundar, K., Mishra, P.K., Mousavi, G., Liu, Z., Gaydo, A., Alem, F., Lagunoff, D., Bleich, D. and Gause, W.C. (2009) Helminth infection can reduce insulitis and type 1 diabetes through CD25- and IL-10-independent mechanisms. Infect. Immun. 77, 5347-5358.

[80] Saunders, K.A., Raine, T., Cooke, A. and Lawrence, C.E. (2007) Inhibition of autoimmune type 1 diabetes by gastrointestinal helminth infection. Infect. Immun. 75, 397-407.

[81] Zaccone, P. and Cooke, A. (2013) Vaccine against autoimmune disease: can helminths or their products provide a therapy? Curr. Op. Immunol. 25, 418423.

[82] Hubner, M.P., Stocker, J.T. and Mitre, E. (2009) Inhibition of type 1 diabetes in filaria-infected non-obese diabetic mice is associated with a T helper type 2 shift and induction of FoxP3(+) regulatory T cells. Immunology (UK) 127, 512-522.

[83] Zaccone, P. and Cooke, A. (2013) Helminth mediated modulation of type 1 diabetes (T1D). Int. J. Parasitol. 43, 311-318.

[84] Hubner, M.P., Shi, Y.H., Torrero, M.N., Mueller, E., Larson, D., Soloviova, K. Gondorf, F., Hoerauf, A., Killoran, K.E., Stocker, J.T., Davies, S.J., Tarbell, K.V. and Mitre, E. (2012) Helminth protection against autoimmune diabetes in nonobese diabetic mice is independent of a type 2 immune shift and requires TGF-beta. J. Immunol. 188, 559-568.

[85] Fleming, J.O., Isaak, A., Lee, J.E., Luzzio, C.C., Carrithers, M.D., Cook, T.D., Field, A.S., Boland, J. and Fabry, Z. (2011) Probiotic helminth administration in relapsing-remitting multiple sclerosis: a phase 1 study. Multiple Sclerosis J. 17, 743-754.

[86] Summers, R.W., Elliott, D.E., Qadir, K., Urban, J.F., Thompson, R. and Weinstock, J.V. (2003) Trichuris suis seems to be safe and possibly effective in the treatment of inflammatory bowel disease. Am. J. Gastroenterol. 98, 2034-2041.

[87] Hubner, M.P., Larson, D., Torrero, M.N., Mueller, E., Shi, Y.H., Killoran, K.E. and Mitre, E. (2011) Anti-Fc epsilon R1 antibody injections activate basophils and mast cells and delay type 1 diabetes onset in NOD mice. Clin. Immunol. 141, 205-217.

[88] Coppieters, K.T., Boettler, T. and von Herrath, M. (2012) Virus infections in type 1 diabetes. Cold Spring Harb. Perspect. Med. 2 (2), a007732.

[89] Adams, S. (1926) The seasonal variation in the onset of acute diabetes: the age and sex factors in 1000 diabetic patients. Arch. Internal Med. 37, 861864.

[90] Yeung, W.C.G., Rawlinson, W.D. and Craig, M.E. (2011) Enterovirus infection and type 1 diabetes mellitus: systematic review and meta-analysis of observational molecular studies. BMJ 342.

[91] Oikarinen, M., Tauriainen, S., Oikarinen, S., Honkanen, T., Collin, P., Rantala, L. Maki, M., Kaukinen, K. and Hyoty, H. (2012) Type 1 diabetes is associated with enterovirus infection in gut mucosa. Diabetes 61, 687-691.

[92] Mercalli, A., Lampasona, V., Klingel, K., Albarello, L., Lombardoni, C., Ekström, J., Sordi, V., Bolla, A., Mariani, A., Bzhalava, D., Dillner, J., Roivainen, M., Bosi, E. and Piemonti, L. (2012) No evidence of enteroviruses in the intestine of patients with type 1 diabetes. Diabetologia 55, 2479-2488.

[93] Dahlquist, G.G., Forsberg, J., Hagenfeldt, L., Boman, J. and Juto, P. (2004) Increased prevalence of enteroviral RNA in blood spots from newborn children who later developed type I diabetes. Diabetes Care 27, 285-286.

[94] Cinek, O., Tapia, G. Witsø, E. Kramna, L., Holkova, K., Rasmussen, T. Stene, L.C. and Rønningen, K.S. (2012) Enterovirus RNA in peripheral blood may be associated with the variants of rs1990760, a common type 1 diabetes associated polymorphism in IFIH1. PLoS ONE 7, e48409.

[95] Simonen-Tikka, M.L. Klemola, P., Suomenrinne, S. Kaijalainen, S. Soderstrom, D., Savolainen-Kopra, C., Nanto-Salonen, K., Ilonen, J., Simell, T., Simell, O. and Roivainen, M. (2013) Virus infections among young childrenthe first year of the INDIS study. J. Med. Virol. 85, 1678-1684.

[96] Simonen-Tikka, M.L., Pflueger, M., Klemola, P., Savolainen-Kopra, C., Smura, T., Hummel, S., Kaijalainen, S., Nuutila, K., Natri, O., Roivainen, M. and Ziegler, A.G. (2011) Human enterovirus infections in children at increased risk for type 1 diabetes: the Babydiet study. Diabetologia 54, 2995-3002.

[97] Beyerlein, A., Wehweck, F., Ziegler, A.G. and Pflueger, M. (2013) Respiratory infections in early life and the development of islet autoimmunity in children at increased type 1 diabetes risk evidence from the BABYDIET study. JAMA Pediatr. 167, 800-807.

[98] Buschard, K., Hastrup, N. and Rygaard, J. (1983) Virus-induced diabetes mellitus in mice and the thymus-dependent immune system. Diabetologia $24,42-46$. 
[99] Sugawara, Y., Hirasawa, K., Takeda, M., Han, J.S. and Doi, K. (1991) Acute infection of encephalomyocarditis (Emc) virus in Syrian-hamsters. J. Vet. Med. Sci. 53, 463-468.

[100] Matsuzaki, H., Doi, K., Mitsuoka, T., Tsuda, T. and Onodera, T. (1989) Experimental encephalomyocarditis virus infection in Mongolian gerbils (Meriones unguiculatus). Vet. Path. 26, 11-17.

[101] Larsen, N., Vogensen, F.K., van den Berg, F.W.J., Nielsen, D.S., Andreasen, A.S., Pedersen, B.K., Al-Soud, W.A., Sørensen, S.J., Hansen, L.H. and Jakobsen, M. (2010) Gut microbiota in human adults with type 2 diabetes differs from non-diabetic adults. PLoS ONE 5, e9085.

[102] Qin, J., Li, Y., Cai, Z., Li, S., Zhu, J., Zhang, F., Liang, S., Zhang, W., Guan, Y., Shen, D., Peng, Y., Zhang, D., Jie, Z., Wu, W., Qin, Y., Xue, W., Li, J., Han, L., Lu, D., Wu, P., Dai, Y., Sun, X., Li, Z., Tang, A., Zhong, S., Li, X., Chen, W., Xu, R., Wang, M., Feng, Q., Gong, M., Yu, J., Zhang, Y., Zhang, M., Hansen, T., Sanchez, G., Raes, J., Falony, G., Okuda, S., Almeida, M., LeChatelier, E., Renault, P., Pons, N., Batto, J.M., Zhang, Z., Chen, H., Yang, R., Zheng, W., Li, S., Yang, H., Wang, J., Ehrlich, S.D., Nielsen, R., Pedersen, O., Kristiansen, K. and Wang, J. (2012) A metagenome-wide association study of gut microbiota in type 2 diabetes. Nature 490, 55-60.

[103] Abrahamsson, T.R., Jakobsson, H.E., Andersson, A.F., Björksten, B., Engstrand, L. and Jenmalm, M.C. (2012) Low diversity of the gut microbiota in infants with atopic eczema. J. Allergy Clin. Immunol. 129, 434-440.

[104] Hansen, C.H.F., Krych, L., Nielsen, D.S., Vogensen, F.K., Hansen, L.H., Sorensen, S.J., Buschard, K. and Hansen, A.K. (2012) Early life treatment with vancomycin propagates Akkermansia muciniphila and reduces diabetes incidence in the NOD mouse. Diabetologia 55, 2285-2294.

[105] Vaarala, O. (2013) Human intestinal microbiota and type 1 diabetes. Curr. Diabetes Rep. 13, 601-607.

[106] Vaarala, O., Atkinson, M.A. and Neu, J. (2008) The "Perfect Storm" for type 1 diabetes: the complex interplay between intestinal microbiota, gut permeability, and mucosal immunity. Diabetes 57, 2555-2562.

[107] Sommer, F. and Backhed, F. (2013) The gut microbiota - masters of host development and physiology. Nat. Rev. Microbiol. 11, 227-238.

[108] Koenig, J.E., Spor, A., Scalfone, N., Fricker, A.D., Stombaugh, J., Knight, R., Angenent, L.T. and Ley, R.E. (2011) Succession of microbial consortia in the developing infant gut microbiome. Proc. Natl. Acad. Sci. 108, 4578-4585.

[109] O’Toole, P.W. and Claesson, M.J. (2010) Gut microbiota: changes throughout the lifespan from infancy to elderly. Int. Dairy J. 20, 281-291.

[110] Yatsunenko, T., Rey, F.E., Manary, M.J., Trehan, I., Dominguez-Bello, M.G., Contreras, M., Magris, M., Hidalgo, G., Baldassano, R.N., Anokhin, A.P., Heath, A.C., Warner, B., Reeder, J., Kuczynski, J., Caporaso, J.G., Lozupone, C.A., Lauber, C., Clemente, J.C., Knights, D., Knight, R. and Gordon, J.I. (2012) Human gut microbiome viewed across age and geography. Nature 486, 222227.

[111] Jost T, Lacroix C, Braegger CP, Rochat F, \& Chassard C (in press) Vertical mother-neonate transfer of maternal gut bacteria via breastfeeding. Environ. Microbiol., doi:10.1111/1462-2920.12238.

[112] Jakobsson, H.E., Abrahamsson, T.R., Jenmalm, M.C., Harris, K., Quince, C., Jernberg, C., Björkstén, B., Engstrand, L. and Andersson, A.F. (2013) Decreased gut microbiota diversity, delayed Bacteroidetes colonisation and reduced Th1 responses in infants delivered by caesarean section. Gut 63, 559-566.

[113] Fallani, M., Young, D., Scott, J., Norin, E., Amarri, S., Adam, R., Aguilera, M., Khanna, S., Gil, A., Edwards, C.A. and Dore, J. (2010) Intestinal microbiota of 6-week-old infants across Europe: geographic influence beyond delivery mode, breast-feeding, and antibiotics. J. Pediatr. Gastroenterol. Nutr. 51, 7784.

[114] Dominguez-Bello, M.G., Costello, E.K., Contreras, M., Magris, M., Hidalgo, G., Fierer, N. and Knight, R. (2010) Delivery mode shapes the acquisition and structure of the initial microbiota across multiple body habitats in newborns. Proc. Natl. Acad. Sci. 107, 11971-11975.

[115] Favier, C.F., Vaughan, E.E., de Vos, W.M. and Akkermans, A.D.L. (2002) Molecular monitoring of succession of bacterial communities in human neonates. Appl. Environ. Microbiol. 68, 219-226.

[116] Palmer, C., Bik, E.M., Digiulio, D.B., Relman, D.A. and Brown, P.O. (2007) Development of the human infant intestinal microbiota. PLoS Biol. 5, e177.

[117] de Goffau, M.C., Luopajärvi, K., Knip, M., Ilonen, J., Ruohtula, T., Härkönen, T., Orivuori, L., Hakala, S., Welling, G.W., Harmsen, H.J. and Vaarala, O. (2013) Fecal microbiota composition differs between children with $\beta$-cell autoimmunity and those without. Diabetes 62, 1238-1244.

[118] Brown, C.T., Davis-Richardson, A.G., Giongo, A., Gano, K.A., Crabb, D.B., Mukherjee, N., Casella, G., Drew, J.C., Ilonen, J., Knip, M., Hyoty, H., Veijola, R., Simell, T., Simell, O., Neu, J., Wasserfall, C.H., Schatz, D., Atkinson, M.A. and Triplett, E.W. (2011) Gut microbiome metagenomics analysis suggests a functional model for the development of autoimmunity for type 1 diabetes. PLoS ONE 6, e25792.

[119] Mejia-Leon, M.E., Petrosino, J.F., Ajami, N.J., Dominguez-Bello, M.G. and de la Barca, A.M.C. (2014) Fecal microbiota imbalance in Mexican children with type 1 diabetes. Sci. Rep. 4, 3814.

[120] Giongo, A., Gano, K.A., Crabb, D.B., Mukherjee, N., Novelo, L.L., Casella, G. Drew, J.C., Ilonen, J., Knip, M., Hyoty, H., Veijola, R., Simell, T., Simell, O., Neu, J., Wasserfall, C.H., Schatz, D., Atkinson, M.A. and Triplett, E.W. (2011) Toward defining the autoimmune microbiome for type 1 diabetes. ISME J. 5, 82-91.

[121] Murri, M., Leiva, I., Gomez-Zumaquero, J.M., Tinahones, F.J., Cardona, F., Soriguer, F. and Queipo-Ortuno, M.I. (2013) Gut microbiota in children with type 1 diabetes differs from that in healthy children: a case-control study. BMC Med. 11, 46, http://dx.doi.org/10.1186/1741-7015-11-46.
[122] Endesfelder, D., Wz, Castell., Ardissone, A., Davis-Richardson, A.G., Achenbach, P., Hagen, M., Pflueger, M., Gano, K.A., Fagen, J.R., Drew, J.C. Brown, C.T., Kolaczkowski, B., Atkinson, M., Schatz, D., Bonifacio, E., Triplett, E.W. and Ziegler, A.G. (2014) Compromised gut microbiota networks in children with anti-islet cell autoimmunity. Diabetes, http://dx.doi.org/ $10.2337 / \mathrm{db} 13-1676$

[123] Le Chatelier, E., Nielsen, T., Qin, J., Prifti, E., Hildebrand, F., Falony, G., Almeida, M., Arumugam, M., Batto, J.M., Kennedy, S., Leonard, P., Li, J., Burgdorf, K., Grarup, N., Jorgensen, T., Brandslund, I., Nielsen, H.B., Juncker, A.S., Bertalan, M., Levenez, F., Pons, N., Rasmussen, S., Sunagawa, S., Tap, J., Tims, S., Zoetendal, E.G., Brunak, S., Clement, K., Dore, J., Kleerebezem, M., Kristiansen, K., Renault, P., Sicheritz-Ponten, T., de Vos, W.M., Zucker, J.D., Raes, J., Hansen, T., MetaHIT consortium, Bork, P., Wang, J., Ehrlich, S.D. and Pedersen, O. (2013) Richness of human gut microbiome correlates with metabolic markers. Nature 500, 541-546.

[124] Cardwell, C.R., Stene, L.C., Joner, G., Cinek, O., Svensson, J., Goldacre, M.J. Parslow, R.C., Pozzilli, P., Brigis, G., Stoyanov, D., Urbonaite, B., Sipetić, S. Schober, E., Ionescu-Tirgoviste, C., Devoti, G., Beaufort, C.E., Buschard, K. and Patterson, C.C. (2008) Caesarean section is associated with an increased risk of childhood-onset type 1 diabetes mellitus: a meta-analysis of observational studies. Diabetologia 51, 726-735.

[125] Salminen, S., Gibson, G.R., McCartney, A.L. and Isolauri, E. (2004) Influence of mode of delivery on gut microbiota composition in seven year old children. Gut 53, 1388-1389.

[126] Wright, D.P., Rosendale, D.I. and Roberton, A.M. (2000) Prevotella enzymes involved in mucin oligosaccharide degradation and evidence for a small operon of genes expressed during growth on mucin. FEMS Microbiol. Lett. 190, 73-79.

[127] Derrien, M., Vaughan, E.E., Plugge, C.M. and de Vos, W.M. (2004) Akkermansic muciniphila gen. nov., sp. nov., a human intestinal mucin-degrading bacterium. Int. J. Syst. Evol. Microbiol. 54, 1469-1476.

[128] Burger-van Paassen, N., Vincent, A., Puiman, P.J., van der Sluis, M., Bouma, J., Boehm, G., van Goudoever, J.B., Van Seuningen, I. and Renes, I.B. (2009) The regulation of intestinal mucin MUC2 expression by short-chain fatty acids: implications for epithelial protection. Biochem. J. 420, 211-219.

[129] Finnie, I.A., Dwarakanath, A.D., Taylor, B.A. and Rhodes, J.M. (1995) Colonic mucin synthesis is increased by sodium butyrate. Gut 36, 93-99.

[130] Derrien, M., van Baarlen, P., Hooiveld, G., Norin, E., Muller, M. and de Vos, W. (2011) Modulation of mucosal immune response, tolerance and proliferation in mice colonized by the mucin-degrader Akkermansia muciniphila. Front. Microbiol. 2, 166, http://dx.doi.org/10.3389/fmicb.2011.00166.

[131] Balderas, C., Ruperez, F.J., Ibanez, E., Senorans, J., Guerrero-Fernandez, J., Casado, I.G., Gracia-Bouthelier, R., Garcia, A. and Barbas, C. (2013) Plasma and urine metabolic fingerprinting of type 1 diabetic children. Electrophoresis 34 2882-2890.

[132] Culeddu, N., Chessa, M., Porcu, M.C., Fresu, P., Tonolo, G., Virgilio, G. and Migaleddu, V. (2012) NMR-based metabolomic study of type 1 diabetes. Metabolomics 8, 1162-1169.

[133] Roesch, L.F.W., Lorca, G.L., Casella, G., Giongo, A., Naranjo, A., Pionzio, A.M., Li, N., Mai, V., Wasserfall, C.H., Schatz, D., Atkinson, M.A., Neu, J. and Triplett, E.W. (2009) Culture-independent identification of gut bacteria correlated with the onset of diabetes in a rat model. ISME J. 3, 536-548.

[134] King, C. and Sarvetnick, N. (2011) The incidence of type-1 diabetes in NOD mice is modulated by restricted flora not germ-free conditions. PLoS ONE 6, e17049.

[135] Alam, C., Bittoun, E., Bhagwat, D., Valkonen, S., Saari, A., Jaakkola, U., Eerola E., Huovinen, P. and Hanninen, A. (2011) Effects of a germ-free environment on gut immune regulation and diabetes progression in non-obese diabetic (NOD) mice. Diabetologia 54, 1398-1406.

[136] Wen, L., Ley, R.E., Volchkov, P.Y., Stranges, P.B., Avanesyan, L., Stonebraker, A.C., Hu, C.Y., Wong, F.S., Szot, G.L., Bluestone, J.A., Gordon, J.I. and Chervonsky, A.V. (2008) Innate immunity and intestinal microbiota in the development of type 1 diabetes. Nature 455, 1109-1113.

[137] Alkanani, A.K., Hara, N., Lien, E., Ir, D., Kotter, C.V., Robertson, C.E., Wagner B.D., Frank, D.N. and Zipris, D. (2014) Induction of diabetes in the RIP-B7.1 mouse model is critically dependent on TLR3 and MyD88 pathways and is associated with alterations in the intestinal microbiome. Diabetes 63, 619631.

[138] Yurkovetskiy, L., Burrows, M., Khan, A., Graham, L., Volchkov, P., Becker, L., Antonopoulos, D., Umesaki, Y. and Chervonsky, A. (2013) Gender bias in autoimmunity is influenced by microbiota. Immunity 39, 400-412.

[139] Markle, J.G.M., Frank, D.N., Mortin-Toth, S., Robertson, C.E., Feazel, L.M Rolle-Kampczyk, U., von Bergen, M., McCoy, K.D., Macpherson, A.J. and Danska, J.S. (2013) Sex differences in the gut microbiome drive hormonedependent regulation of autoimmunity. Science 339, 1084-1088.

[140] Mittelstrass, K., Ried, J.S., Yu, Z., Krumsiek, J., Gieger, C., Prehn, C., RoemischMargl, W., Polonikov, A., Peters, A., Theis, F.J., Meitinger, T., Kronenberg, F., Weidinger, S., Wichmann, H.E., Suhre, K., Wang-Sattler, R., Adamski, J. and Illig, T. (2011) Discovery of sexual dimorphisms in metabolic and genetic biomarkers. PLoS Genet. 7, e1002215.

[141] Gale, E.A.M. and Gillespie, K.M. (2001) Diabetes and gender. Diabetologia 44 $3-15$.

[142] Kriegel, M.A., Sefik, E., Hill, J.A., Wu, H.J., Benoist, C. and Mathis, D. (2011) Naturally transmitted segmented filamentous bacteria segregate with diabetes protection in nonobese diabetic mice. Proc. Nat. Acad. Sci. 108, 11548-11553. 
[143] Gaboriau-Routhiau, V., Rakotobe, S., Lecuyer, E., Mulder, I., Lan, A., Bridonneau, C., Rochet, V., Pisi, A., De Paepe, M., Brandi, G., Eberl, G., Snel, J., Kelly, D. and Cerf-Bensussan, N. (2009) The key role of segmented filamentous bacteria in the coordinated maturation of gut helper $\mathrm{T}$ cell responses. Immunity 31, 677-689.

[144] Schnupf, P., Gaboriau-Routhiau, V. and Cerf-Bensussan, N. (2013) Host interactions with segmented filamentous bacteria: an unusual trade-off that drives the post-natal maturation of the gut immune system. Sem. Immunol. $25,342-351$.

[145] Ivanov, I.I., Atarashi, K., Manel, N., Brodie, E.L., Shima, T., Karaoz, U., Wei, D.G., Goldfarb, K.C., Santee, C.A., Lynch, S.V., Tanoue, T., Imaoka, A., Itoh, K., Takeda, K., Umesaki, Y., Honda, K. and Littman, D.R. (2009) Induction of intestinal Th17 cells by segmented filamentous bacteria. Cell 139, 485-498.

[146] Mathis, D. and Benoist, C. (2012) The influence of the microbiota on type-1 diabetes: on the threshold of a leap forward in our understanding. Immunol Rev. 245, 239-249.

[147] Brugman, S., Klatter, F.A., Visser, J.T.J., Wildeboer-Veloo, A.C.M., Harmsen, H.J.M., Rozing, J. and Bos, N.A. (2006) Antibiotic treatment partially protects against type 1 diabetes in the Bio-Breeding diabetes-prone rat. Is the gut flora involved in the development of type 1 diabetes? Diabetologia 49, 2105 2108.

[148] Hageman, I. and Buschard, K. (2002) Antidiabetogenic effect of fusidic acid in diabetes prone BB rats: a sex-dependent organ accumulation of the drug is seen. Pharmacol. Toxicol. 91, 123-128.
[149] Ogasawara, K., Hamerman, J.A., Ehrlich, L.R., Bour-Jordan, H., Santamaria, P., Bluestone, J.A. and Lanier, L.L. (2004) NKG2D blockade prevents autoimmune diabetes in NOD mice. Immunity 20, 757-767.

[150] Rodacki, M., Svoren, B., Butty, V., Besse, W., Laffel, L., Benoist, C. and Mathis, D. (2007) Altered natural killer cells in type 1 diabetic patients. Diabetes 56, 177-185.

[151] Hansen, C.H.F., Holm, T.L., Krych, L., Andresen, L., Nielsen, D.S., Rune, I., Hansen, A.K. and Skov, S. (2013) Gut microbiota regulates NKG2D ligand expression on intestinal epithelial cells. Eur. J. Immunol. 43, 447-457.

[152] Calcinaro, F., Dionisi, S., Marinaro, M., Candeloro, P., Bonato, V., Marzotti, S., Corneli, R.B., Ferretti, E., Gulino, A., Grasso, F., De Simone, C., Di Mario, U., Falorni, A., Boirivant, M. and Dotta, F. (2005) Oral probiotic administration induces interleukin-10 production and prevents spontaneous autoimmune diabetes in the non-obese diabetic mouse. Diabetologia 48, 1565-1575.

[153] Murphy, E.F., Cotter, P.D., Hogan, A., O’Sullivan, O., Joyce, A., Fouhy, F., Clarke, S.F., Marques, T.M., O’Toole, P.W., Stanton, C., Quigley, E.M.M., Daly, C., Ross, P.R., O'Doherty, R.M. and Shanahan, F. (2013) Divergent metabolic outcomes arising from targeted manipulation of the gut microbiota in diet-induced obesity. Gut 62, 220-226.

[154] Reyes, A., Wu, M., McNulty, N.P., Rohwer, F.L. and Gordon, J.I. (2013) Gnotobiotic mouse model of phage-bacterial host dynamics in the human gut. Proc. Nat. Acad. Sci. 110, 20236-20241. 